\title{
Common faults in college orations
}

\section{R. D. T. Hollister}

To cite this article: R. D. T. Hollister (1918) Common faults in college orations, Quarterly Journal of Speech, 4:3, 311-323, DOI: 10.1080/00335631809360683

To link to this article: http://dx.doi.org/10.1080/00335631809360683

\section{册 Published online: 05 Jun 2009.}

Submit your article to this journal 주다

Џll Article views: 3

Q View related articles $₫$ 


\title{
COMMON FAULTS IN COLLEGE ORATIONS
}

\author{
R. D. T. HOLLISTER \\ University of Michigan
}

In discussing this subject, it is not my purpose to try to identify and classify all the faults that may be found in college orations. Such a study would involve the whole problem of preparing and delivering a speech. Nor is it my desire to complain of the products or belittle the value of oratorical contests. Such contests, in spite of the criticisms that may be made against them, have a real educational value, and their products in many cases show the highest rhetorical excellence. If one will read the winning speeches of the Northern Oratorical League or of the Interstate Oratorical contests, he will find many examples of clear, forceful, persuasive composition. We must recognize, however, that the usual college orations, the ones presented in preliminaries and even those selected for intercollegiate contest, are bound to have serious defects, some of which are quite common. It is my purpose to remind you of some of the more characteristic faults in order that we as teachers may be more helpful to students preparing for oratorical contests.

I shall limit my discussion to faults that come in violation to two important principles. These I shall call (1) mental-emotional balance, and (2) forward movement towards a climax. These principles, while distinct, are closely related, and are often violated by the same fault.

I. The principle of mental-emotional balance requires that the thought and feeling shall be so poised that neither completely out-weighs the other. At times the emotion may be stronger than the thought, and at other times the thought stronger than the emotion, but at no time should the emotion become so excessive that the thought is not clearly realized, nor the thought so cold that the emotion is killed. In general, the mental and emotional interest should rise and fall together, with the mental interest slightly stronger most of the time. The emotion is not to be suppressed towards elimination, but is to be given the greatest freedom consistent with a clear, intense realization of the thought. The thought should

$r$ ominant. As it grows in power, the emotion may increase, 
but the emotion should not be uniformly strong when the thought is uniformly weak, nor the thought uniformly strong when the emotion is uniformly weak. Each should harmonize with the other. In fact, such harmony is essential to the greatest strength of both.

The principle of mental-emotional balance requires that in all forms of speaking the thought shall be so clearly communicated to the audience that it gives them the mental substance from which the emotion springs. Even in the oral interpretation of lyric poetry, where the spirit of self-expression seems all powerful, where the speaker seems unconscious of an actual audience, the spirit of clear realization of the thought,-of strong communication to self, is essential to the maintenance of mental-emotional balance. Wherever the spirit of self-expression is dominant, the spirit of communication should be kept strong. It should not, however, be allowed to destroy the emotion which the spirit of self-expression creates.

In the majority of cases, the problem of maintaining a mentalemotional balance is the problem of keeping the spirit of communication strong. This is especially true in college orations for in these the tendency towards excessive emotion is common. This tendency is due in part to the fact that orations must be on emotional themes, nonemotional themes are not suited to oratorical treatment. Themes that are coldly intellectual whose interest goes no deeper than the satisfaction of mental curiosity, and whose aim is information only, do not have intrinsic power to lift the speaker and audience above the commonplace. The theme of an oration must touch life's needs directly and deeply. It must be of vital personal or public interest. It must have strong persuasive possibilities,-something that can grip the speaker and stir the audience. Such subjects as "The Habits of the Toad" and "The Action of the Crico-thyroid Muscle" cannot do this. Their emotional appeal is so weak that they preclude the possibility of earnestly persuasive speech. Themes for orations must be rich in emotional possibilities,-richer usually that subjects for debates or topics for extemporaneous discussion; and out of this very richness springs the danger of excessive emotion.

Another cause of this tendency towards excessive emotion in college orations may be the time limit placed upon them. It may be that this time is too short for the adequate presentation of the intellectual background of a vital theme, and that the speaker 
must confine himself to general conclusions and cannot give the thought materials on which these conclusions are based. It is certain that this time limit makes it necessary to exclude many things, and thus intensifies the problem of retaining the most important things. And since the general conclusions in the speaker's mind are apt to seem more important to him than the facts and reasons upon which they are based, he is in danger of overemphasizing these generalities. He omits the intellectual background without which his emotion seems inflated. His speech becomes but the emotional part of a longer speech, and he ascends so abruptly to a high emotional level that the audience cannot follow him.

To my mind, however, the fundamental cause of this emotional separation between speaker and audience is not the time limit. While the time limit may make the temptation towards excessive emotion stronger, it is not the chief cause of this fault. A more fundamental and more common cause is, not too little time in which to present the intellectual background of the subject, but too little intellectual background to present. The time allowed is really too long for what the speaker has to say. Consequently he must fill it up with irrelevant philosophy and history, with overdrawn description, and with prolonged and repeated appeals. $\mathrm{He}$ is stirred with a general idea of a vital message, but does not do sufficient reading and investigation. How do students usually prepare orations? They know a contest is coming and decide to enter it. They get a line of thought that appeals to them, and then trust largely to their own information to develop it. If they have a desire to read, in many cases they do not know what to read. They write without a definite plan of the speech worked out. They pay more attention to the style of expression than to the force of ideas. They look at winning speeches and masterpieces of oratory and strive to shape their style after these models. Too often they prepare to impress an audience and win a contest, rather than to impress themselves with truth and to express in a simple and spontaneous manner the things they have thought and felt. Sometimes the preparation is left until the eleventh hour, with the result that the thought is only half clear. Thus the burden of winning is shifted to the delivery, and this must be noisy with emotion in order to cover up the lack of clear, vigorous thought. 
Three of the general causes, then, of excessive emotion in college orations are (1) the emotional richness of the subjects treated, (2) the limited time for their treatment, and (3) inadequate and misconceived preparation.

In our consideration of the principle of mental-emotional balance, however, we must not forget that while the danger of excessive emotion causes many characteristic faults in college orations, the lack of strong emotional response in the majority of students, often in those whose intellectual powers are keen, makes it difficult for them to succeed in oratorical contests. Lack of genuine emotional fire is one of the most serious handicaps to students of oratory. Emotional power is essential to the highest success, but this power, like all great power, is useless and dangerous if not controlled. However, in our efforts to control it in students we should try not to weaken it, but rather to put it under the mastery of clear, energized thinking. It is not less emotional steam that is needed in orations, but a stronger intellectual engine for the control and utilization of the same.

When we read orations and listen to oratorical contests we soon discover concrete evidence of the violation of mental-emotional balance. In printed speeches, we find this, first, in the subjects announced. Such subjects as "The March of the Constitution," "The Battle with Lawlessness," "The Master Force of Progress," "After the Shackles have been Removed," "Modern Feudalism," "The New Prometheus," "The Grim Chieftain," and "The Imperishable State," point towards emotional inflation, and a tendency of the speaker to outrun his audience.

A second evidence of the lack of mental-emotional balance is seen in the strained style of introductions. This shows itself in the attempt to use striking sentences, epigrams, antitheses, and weighty thoughts at the very beginning. This fault is illustrated in the following:

"Political and religious reforms move slowly. We change our beliefs and at the same time hold fast to old customs."

${ }^{6}$ Kings may reign, parliaments may govern, but public opinion is the ultimate source of power."

${ }^{66}$ History is made by thought, not by victorious arms; its periods are marked by advance, not by monumental granite. Men die, but their influence goes on forever." 
"America's watchword has been sounded. Across the land like a mighty trumpet-call has gone forth the cry, Prepare! To-day our big guns point outward; our harbors are mined, our defenses are strengthened for action. But America's preparedness depends on more than guns and ammunition; it depends on a strong united citizenry, and, ladies and gentlemen, we are awakening in the shadow of the world's greatest war to find that in that vital inner preparedness the United States of America is woefully lacking. We are giving thought to biplane and dreadnaught and submarine, but we are neglecting to Americanize our immigrant."

The sudden descent from "America's watchword" to "ladies and gentlemen" is an interesting reversal of the natural order of growth in emotional interest.

Strained style in the introduction also shows itself in the attempt to use impressive description and thrilling narration. An easy narrative style at the beginning of a speech is desirable when well used. But when overworked, it destroys the mental-emotional balance. In the following the abrupt introduction of the historical present asks too much of the imagination of the audience.

"It is noontide in a quiet Southern town. The habitual languid life is roused to commotion as deputies lead a dusky prisoner to his trial."

The poetic usage seen in the words noontide and dusky also suggest inflation of style.

In the following the details of the picture demand more than the audience will see.

"Before the massive structure of an American Industry stands the lonely figure of an aged workman. The knarled hands, the drooping shoulders, the blended spine, the blank face, bespeak a life of constant toil, while the hollow eyes, the sunken cheeks, and the tattered garments hanging from his wasted body tell the story of privation and want. Leaning heavily upon his cane, the old man stands for a moment gazing upon the great clouds of smoke pouring from the giant funnels of the foundry, then slowly turned and silently crept away. This man typifies the living tragedy in the human scrap-heap of American industry."

The historical present, the heaping up of adjectives, the poetic usage, the shift of tense, and the incongruity of "the living tragedy of the human scrap-heap of American industry," are evidence of the inflation of this introduction. 
Here are two other examples of overworked description and narration, both presented in the same contest of the Northern Oratorical League.

"The gray September day closed on the life of Paris. The wheels of toil had ceased their dreary rounds. The laborers, worn with the day's work, had returned to their homes. France's Capital was at rest, save a score of earnest statesmen who wrestled with a weighty problem; twenty men in whose hands lay the freedom of an enslaved people."

"Three hundred years ago, on the eve of St. Bartholomew's day, Paris lay shrouded in the shadows of evening. Vender's cry and rattling cart were muffled in the folds of dusk. The ancient buildings were wrapped in the stillness and calm of night. After the rumble and roar of the day's traffic, Paris lay at rest."

Still another evidence of a strained style in the introduction is the premature use of figures of speech, especially poor ones. This fault is frequently associated, as in the following examples, with a balancing of phrases and a repetition of the same form of sentence structure which results in a rhythm not suited to the introduction.

"The history of nations is written in the biographies of its leaders. Its destiny is formed by pioneer thinkers who blaze the trails for national development. Cavour, fired by nationalistic dreams, raised the rock wastes of Piedmont into a European power. Bismark, dreaming of a German empire, waved a wand of diplomacy over scattered provinces, and from these fragments arose an organized state. Gladstone, spurred by moral zeal, forced British pride to accept the principles of international arbitration. Likewise, one of our leaders, James Monroe, gave America a far-reaching principle."

"Perhaps no period of equal length has been so crowded with political events as the closing quarter of the nineteenth century. China, wrapped in the grave clothes of antiquity, has come forth from the tomb of Oriental seclusion. Germany's petty kingdoms, under the titanic hand of Bismark, have been welded into the strength of empire. Liberalism, leaping from the brow of Gladstone, has thrown wide the castle doors of English conservatism. The Teutonic idea of democracy seems to represent 'the tide and passion of the time.' Its upheaving power has altered the history of imperialism and has shifted the world's political center of gravity." 
"History is made by thought, not by victorious arms; its periods are marked by advances, not by monumental granite. Men die, but their influence goes on forever. Their thoughts, marshalled by Truth, drive bigot Error from the temple of Religion, and strike from the limbs of bondmen the chains of oppression. A Roger Williams, driven from the fireside of Puritan piety, establishes on the bleak shores of Rhode Island a colony which has for the rock of its foundation freedom of conscience. John Brown hurls himself against the institution of slavery, and the startled South sends him to the scaffold. But his spirit goes marching on before triumphant armies, until they bivouac amid the gleaming watch-fires of emancipated freedom."

If we could study these examples closely, we would find several indications of strained style.

A strained style is not confined to the introduction. The presence of vague, shifting figures of speech, and of forced or borrowed style is too often found through the body of the speech. The following will illustrate this fact.

"When the siren song of state rights was luring the republic on the rocks of disunion, there came a Marshall."

"Our mission is to strike the chains from the ankles of warburdened humanity."

"For the past century she (Russia) has been creeping with stealthy but certain tread into the byways of the Orient, until to-day her tyrannical hand has its clutches on more than onesixth of the entire globe."

The incongruity in these is apparent. War-burdened does not suggest chains on ankles, creeping and stealthy are out of harmony with certain tread, while a hand clutching one-sixth of the globe suggests the cartoonist's imagination.

The following is a more extended riot of figures:

"Spain's colonial empire, built as it was on the quicksands of a government by force had crumbled and fallen into decay. For nearly a century the coast towns of South America were caught in the web of British pirates. In this benighted continent a myriad of men and women bowed in abject terror to the Spanish inquisition. Here was a people fearing to cast off the shackles of a crumbling government, lest they should feel the reforged chains of a new enemy close about them. 
"In this momentous hour the United States blazed across the horizon of a new continent, the Monroe Doctrine. Out upon the stormy waves of the Atlantic, beyond the blue waters of the Mexican Gulf and the Carribean Sea, soared the new Monroe Doctrine, impersonating the American eagle itself, one of whose wings was beating off the Old World powers, while the other was struggling for supremacy against the activities of the Orient. Impressed and inspired by this manifestation of national unselfishness, the Southern countries accepted the Monroe Doctrine with gratitude and joy. They at once began to organize governments modeled after their strong neighbor on the north. They demonstrated to the world that an oppressed people, downtrodden in ignorance and superstition, could rise out of this hopeless tangle of jungle and swamp, and conquer themselves. *** "The Monroe Doctrine, the altruistic moral wall which we flung around South America in her infancy."

Any one who is familiar with the speeches of Ingersoll and Phillips will recognize the borrowed style in the following:

"By whom is this verdict rendered? *** Not by those who bivouacked in simple fellowship with him (Napoleon) at Marengo, at Austerlitz, *** who swept with him and the eagles over the threatening Alps and through the laughing valleys of Italy, and trod with him the blood-stained snows of Russia."

"Now, if you were to relate the career of Washington, you would take it from the testimony of the loyal American, not from the British Tory. If you wished to determine the motives of Cromwell, you would find them written in the heart of English Puritans, not in the annals of the Royalists. 'If I stood here tonight to tell the story of Napoleon,' exclaimed Wendell Phillips, 'I would take it from the lips of Frenchmen, who find no language rich enough to paint the great captain of the nineteenth century.' But in dealing with his story to-night, we must take it from the lips of Englishmen, Germans, and Russians, who despised this powerful enemy of monarchies and aristocracies, - this low-born emperor of the people,-and who hated them because he had beaten them in battle.

"We might compare him to Washington, but he was a more consummate genius than the great American, and had not the sea to save him from the wrath of his foes. We might compare him to Cromwell, but the great Puritan fought only a portion of his 
own people, while the emperor of the French contended against the allied forces of Europe. We might compare him to Augustus Caesar, but the great Roman $* * *$ " etc.

Still another violation of the principle of mental-emotional balance is exaggeration in thought rather than in style. The following seem to me to illustrate this fault.

"Thrift implies a wage margin above the level of mere subsistence,-a margin which three-fourths of all the male workers do not enjoy. $* * *$ The practice of thrift by a family already struggling to secure the bare necessities of life; by a family deprived of recreation, education, and a moments surcease from the dread and fear of hunger; by a family unable to provide efficient medical aid for its sick, or a decent burial for its dead, would mean to lower the present standard of living below the level of animal existence, and to give to posterity a race of physical, mental, and moral starvelings."

"Ten million people (in the United States) do not get enough to eat. $* * *$ One-half of our adult workers receive less than the minimum we call a living wage."

Such statements as these without proof seem over-emotional. Exaggeration may sometimes be necessary to arouse an audience, but it often becomes a fault.

The faults that spring from a violation of the principle of mentalemotional balance are not confined to the composition of an oration, but may be heard in the delivery of a speech. In fact, a composition with good mental-emotional balance may have this destroyed by the delivery. First, the vocalization may be uniformly full and noisy, the sound covering up the sense. The bellow of the orotund and the awe-inspiring solemnity of the pectoral may swallow up the still small voice of the thought. Lack of variety in pitch, rate, touch, and tone,-uniformity in inflection, melody, speed, grouping, intensity, and vocal fullness, - often makes a clear, intense transmission of the thought impossible. It results in a succession of vocal sounds in which a monotonous mood is strong, but the thought obscure. Part of this unbalancing of the mental and emotional interest may come directly from the speaker's inability to enunciate with perfect distinctness. Perfect enunciation will help a speaker to control tones which would otherwise be too full, hollow, breathy, or noisy for the thought. 
The stage behavior of the speaker often violates the principle of mental-emotional balance. Any conscious attempt to produce an effect upon the audience will do this. An attempt at the beginning of the speech to command the attention of the audience by studied deliberation, or a conscious setting-up of the physical personality, or a steady sweep of the eyes over the vast assembly, will make the appearance stronger than the spirit back of it and destroy that spontaneity and genuineness which justifies all action. Deliberation is important, and the setting-up of physical personality wholly desirable, but these things should be consciously practiced in preparation for the speech, and not while the speaker faces his audience. When one is in the thick of battle, setting-up exercises should shift for themselves.

This idea also applies to gesture. Gestures should be practiced until the speaker uses them without knowing it. "Canned" gestures, the frequent use of first one hand and then the other, and the use of both arms fully extended, are common evidence of lack of mental emotional balance. Whenever form is evident, the sense is obscured. The principle of mental-emotional balance requires that form shall be subservient to substance.

Dr. Lyman Beecher was returning from church one Sunday with his son, Henry Ward Beecher, when Henry Ward Beecher was a boy. Dr. Beecher seemed very much depressed, and his son asked the reason. "I never preached a poorer sermon in my life," said Dr. Beecher.

"Why, father," said his son, "I never heard you preach louder."

"That's just it," said Dr. Beecher, "When I haven't much to say I always holler."

When noise and gesture get in the way, thought has a slim chance.

Let us now consider briefly the second principle commonly violated in college orations, the principle of forward movement towards a climax. In brief, this piinciple requires that the thought of a speech shall grow until it bears the ripened fruit; that flowers of thought,-imagination and music, expressing themselves in figurative language and rhythmical style, -shall not be placed among the roots; that the introduction shall be relatively unemotional, free from figures of speech, and from poetic tendencies. It requires that the thought and emotion shall have a cummulative effect. 
A splendid application of this principle may be studied in Lincoln's Second Inaugural Address. Here, the emotion rises easily yet quickly from the simple statement, "At this second appearing to take the oath of the Presidential office, there is less occasion for an extended address than there was at first." It grows through the ideas that "On the occasion corresponding to this four years ago, all thoughts were anxiously directed to an impending civil war," that "Neither party expected for the war the magnitude or the duration which it has already attained," that "Each looked for an easier triumph, and a result less fundamental and astounding," that "Both read the same Bible and pray to the same God," but that "The prayer of both could not be answered." The emotion strengthens itself with the hope that "this mighty scourge of war may speedily pass away," and with the declaration that "if God wills" the war shall continue; and it reaches its climax in the sublime appeal at the close:

${ }^{66}$ With malice towards none, with charity for all, with firmness in the right as God gives us to see the right, let us finish the work we are in, to bind up the nation's wounds, to care for him who shall have borne the battle, and for his widow and his orphans, and to do all which may achieve and cherish a just and lasting peace among ourselves and with all nations."

Violations of this principal of forward movement may come from several sources. The student may not have a practical appreciation of the principle. He may never have felt it strongly in his nerves and muscles. Besides, ideas may all feel about alike to him. Then his sense of the logical relationship of ideas may be weak, and his ability to make a clear, orderly plan undeveloped.

A common way of violating this principle, as already suggested, is excessive emotion in the introduction. Another way is by a weak deductive plan in which the most important idea is so strongly presented early in the speech that the following development adds nothing to the power of this idea. Still another way is by a weak inductive plan in which startling facts, striking scenes, and eloquent passages are thrown together without proper association and interpretation. A more common way is the introduction of unnecessary history in which the evolution of the idea is traced from its remote ancestors. One of the most characteristic violations of this principle, and the only one I shall illustrate, is the use of false leads. 
This tendency to start ideas that should not be suggested is especially strong in the introduction. Practically every speech in the Northern Oratorical League last year presented ideas in the introduction that did not start a forward development of the main idea and in some cases turned the thought towards other ideas of greater interest than the ones presented.

In the winning speech, where the central idea was the Americanization of the immigrant, the first thought suggested was the demand for military preparedness. In the speech winning second honor the main thought hovered about the idea that the scholar should work for better economic adjustment, but the introductory thought was that democracy and despotism were struggling in Europe, and that Americanization must mean a great democracy. A speech on the Monroe Doctrine began with a statement that "history is written in biographies." It then introduced Cavour, Bismark, and Gladstone, then James Monroe. Then the thought shifted from biographies to the Monroe Doctrine.

This false lead is such a common and flagrant fault that I want to emphasize it by further illustration. The first is the introduction to a speech on "The Cry of Humanity."

"We are living in an era marked by tremendous, unsolved problems. We are face to face with such questions as our merchant marine, monopoly in business, immigration, and international peace. Preplexing as these questions are, they must yield in importance, even as others have yielded before them, to the problem of problems-the plight of the toiler."

The following is the beginning of a speech on "Industrial diseases."

${ }^{6}$ In the early part of the eighteenth century, when the frontier began to march across the American continent, one-half of the present area of the United States was still covered by the primeval forest. It was a magnificent empire of eight hundred fifty million acres containing four thousand billion feet of merchantable timber. There was a heritage, which for immensity and for variety of species had never been equaled. So vast and so apparently unending were the reaches of the forest that the nation confidently believed its resources could never be exhausted. It was for this reason that every one accepted with complacency the era of ruthless waste that had already begun; no one offered to protest when the lumber companies of the frontier left behind them their characteristic 
trail of devastation. The very magnificence of the heritage generated in the optimistic west a spirit of reckless disregard for waste. What though the waste be large! Lumber is cheap, and the supply is unlimited!

"In this spirit of careless optimism lies the tragedy of the forest. In this spirit lies the tragedy of wasted minerals and depleted soils. In this spirit lies the saddest tragedy of all, the tragedy of wasted labor."

False leads are not confined to the introduction. If we could analyze several speeches, we would find many instances where forward movement towards a climax is stopped by the introduction of diverting ideas.

I have discussed two principles which are commonly violated in college orations. Ways of preventing some of these violations have occurred to each of you. My concluding suggestions are these:

First, we should insist that students preparing for oratorical contests state in a clear, concise sentence their central thought. Second, that they shall, before writing, submit a detailed outline of their ideas, and that each idea shall be clearly expounded, general assertions backed up, and unnecessary ideas eliminated. Third that reading and investigation be more extensive. Fourth, that a simple style in introduction be used, and that all struggle for effect in composition and delivery be subordinated to the substance of the message.

While I have emphasized the faults in college orations, I would not forget their virtues, nor eliminate oratorical contests. The art of writing and delivering an effective short oration demands the best thinking, the best writing, and the best speaking a student can give, and is an art to aid which teachers of Public Speaking may profitably devote their best efforts. 